\title{
Burgerlike Ongehoorsaamheid
}

J A Heyns

\author{
Abstract
}

\section{Civil Disobedience}

For a twofold reason civil disobedience is currently a well known phenomenon not only in South Africa but also in different countries in the rest of the world. Firstly because it is practised by more people more frequently as a means of solving political problems, and secondly because more people are justifying it on theological grounds. After an attempt at a satisfactory definition an analysis is made of civil disobedience from a social ethical perspective. Certain fundamental aspects then come under scrutiny and the principal background for civil disobedience is supplied Having given a short critical evaluation the article ends with some positive guideliness.

\section{Inleidend}

Wie meelewe met die sosio-politieke gebeure nie net in Suid-Afrika nie, maar ook in talle dele van die wêreld, sal weet dat die verskynsel van burgerlike ongehoorsaamheid in toenemende mate nie net gepraktiseer word nie, maar ook teoreties verdedig word. Om dié rede sal enkele - hopelik verhelderende - opmerkinge hieroor sekerlik nie onvanpas wees nie.

Met die tema van burgerlike ongehoorsaamheid het ons die terrein van egte konflikhandelinge binne staatsverband betree. Die feit dat die staat ' $n$ instelling van God is, en gehoorsaamheid aan die handelinge van die owerheid daarom verwag word, het nie verhinder nie dat daar deur die eeue heen mense was wat nie net ernstige kritiek teen die owerhede gehad het nie, maar hulle selfs ook teen die owerhede verset het, soms sonder geweld, maar dikwels ook met geweld. Uiteraard was daar ook kontrahandelinge van die staat en ook dit het tot die intensiteit van die konflik bygedra. En vanselfsprekend is die gewetensvraag gestel: mag die Christen hieraan meedoen? As die staat ' $n$ instelling van God is waaraan gehoorsaamheid betoon moet word, en dit staan vir die Christen, op grond van die Skrif vas, het hy hoegenaamd enige keuse om nie gehoorsaam te wees nie? En as hy ongehoorsaam mag wees, onder watter omstandighede en op watter gronde mag dit gebeur? Maar nie net die Christenburger het gewetensvrae om te beantwoord nie. Ook die owerheid, en met name die Christelike owerheid, staan voor fundamentele vraagstukke: presies hóe word ten opsigte van die verskillende gestaltes van ongehoorsaamheid opgetree, want dat daar opgetree móét word lê wesenlik in die roeping van die staat opgesluit.

Die term burgerlike ongehoorsaamheid is nie baie oud nie ${ }^{1}$, maar die saak, naamlik ongehoorsaamheid aan die owerheid, of aan amptelike instansies en maatreëls, kom vroeg in die geskiedenis al voor. Reeds in Eksodus 1:17 lees ons dat die Hebreeuse vroedvroue Sifra en Pua nie die Joodse seuntjies doodgemaak het soos die Egiptiese koning hulle geveel het om te doen nie, en toe hulle om rekenskap gevra is het hulle nie die volle waarheid meegedeel nie. Anders as by burgerlike ongehoorsaamheid het 
hulle daad van ongehoorsaamheid egter nie openlikplaasgevind nie. Gehoorsaamheid aan God het hier ongehoorsaamheid aan Farao beteken. Volgens 1 Konings 18:3 het Obadja, wat die Here pligsgetrou gedien het, honderd profete weggesteek toe Isebel besig was om die profete van die Here dood te maak. In stryd met die dekreet van koning Darius dat hy alleen vir dertig dae aanbid moet word, het Daniël voortgegaan om God te aanbid (6:11). En in Handelinge 17:7 lees ons dat Paulus, in stryd met die keiser se wette, die evangelie in Tessalonika verkondig het. As voorbeelde van ongehoorsaamheid aan die owerheid kan ook bekende figure buite die Bybel genoem word soos Sokrates, Mahatma Gandhi en ML King. Ons het hier wel met ongehoorsaamheid te doen, maar is dit nou ook burgerlike ongehoorsaamheid? ${ }^{2}$. Presies wát word daarmee bedoel, waarin stem dit ooreen met en waarin verskil dit van gewone ongehoorsaamheid, en wat sê die teologiese etiek daarvan?

Dit sou nie verkeerd wees om te sê dat in die Gereformeerde teologie, en in die etiek wat hierby aansluit, daar nog nie veel aandag aan die verskynsel van burgerlike ongehoorsaamheid gegee is nie. Trouens, daar sou selfs gevra kon word of burgerlike ongehoorsaamheid hoegenaamd pas in 'n beskouing - tipies van die Gereformeerde teologie - waar die staat beklee is mel gesag wat aan God self ontleen word? Pas dit nie eerder in die kader van 'n sosiale-kontrakteorie waarvolgens die volk gesag aan die staat verleen en daarmee ook regeerbevoegdheid aan die staat oordra en waardeur die volk gevolglik ' $n$ soort monitorfunksie ten opsigte van die owerheid se optrede verkry nie? ? $^{3}$. ' $n$ Mens sou selís kon vra of die term burgerlike ongehoorsaamheid nie 'n selfweerspreking is nie: 'n burger is tog per definlsie gehoorsaam aan die wette van sy land, daarom sal ongehoorsaamheid sy burgerskap kanselleer. Dit mag wel logies waar wees, maar prakties gaan dit nie op nie, want burgerskap beteken sekerlik nie dat alles wat die owerheid doen ten volle gehoorsaam moet of kan word nie. En natuurlik ook omgekeerd: die burger wat ongehoorsaam is, verloor nie outomaties sy burgerskap nie.

\section{Omskrywing}

'n Groot verskeidenheid definisies van burgerlike ongehoorsaamheid kan uit die beperkte literatuur versamel word ${ }^{4}$. As uitgangspunt van ons bespreking en in aansluiting by formuleringe wat al reeds gegee is, wil ons burgerlike ongehoorsaamheid in die algemeen omskryf as ' $n$ openbare onwettige, nie-geweldadige aksie van morele protes teen 'n bestaande wet of wette of dele daarvan. Enkele opmerkings ter verheldering van hierdie omskrywing is nodig.

Ons begin deur allereers daarop te wys dat burgerlike ongehoorsaamheid as 'n stuk politieke protes, ' $n$ handeling is wat deur ' $n$ burger van die staat verrig word. Die burger staan tot die staat in 'n duidelik omskrewe vaste verhouding waarin die staat ten opsigte van die burger en die burger ten opsigte van die staat sekere eise en verpligtinge het. In die daad van burgerlike ongehoorsaamheid kom die burger nie sy verpligting teenoor die staat na nie, want in plaas van gehoorsaam te wees, is hy ongehoorsaam. Maar hy is ongehoorsaam op ' $n$ burgerlike en nie byvoorbeeld op ' $n$ militêre wyse nie. As burger beskik hy nie oor militêre wapens nie, daarom is sy ongehoorsaamheid nie militêre of gewelddadige verset nie, maar 'n ongehoorsaamheid in gesindheid, woord en daad. Terwyl geweld prinsipieel verwerp word, word erken dat die staat alleen 
geweld mag hanteer, waar dit nodig is. As burger wil hy nie pnbeskaatd optree nie, daarom is sy ongehoorsaamheid die resultaat van 'n intelligente meelewing met die gebeure van die dag, en gun hy, ten spyte van die daad van sy ongehoorsaamheid, ruimte aan diegene wat ' $n$ ander mening daarop nahou. Burgerlike ongehoorsaamheid is nie ' $n$ private of geheimsinnige handeling van ' $n$ eksklusiewe groepie mense nie. Dit is ' $n$ openbare saak waaraan almal wat ' $n$ bepaalde mening toegedaan is, mag meedoen. Wie burgerlik ongehoorsaam is, wil hom nie ten volle onttrek aan alle sosiale verantwoordelikhede nie, ewe min wil hy alle voordele van die samelewing ontbeer. Maar met betrekking tot bepaalde sake huldig hy ' $n$ ander mening as die owerheid en ten opsigte dáárvan gaan hy 'n ander weg'. En die weg wat hy gaan is nie uitsluitlik of noodwendig ' $n$ weg van eie persoonlike belang nie, maar ' $n$ optrede wat die belange van die groep waarmee hy hom vereenselwig, wil dien. Só verstaan is dit verder duidelik dat burgerlike ongehoorsaamheid nie 'n gebeure is wat binne die parlement met parlementariërs as deelnemers afspeel nie. Dit is ' $n$ buiteparlementêre optrede van burgers wat nie self die wette maak nie, maar veronderstel is om die wette wat vir hulle gemaak is, te gehoorsaam. In die wete dat sy ongehoorsaamheid inderdaad ' $n$ oortreding is, is die burgerlike ongehoorsame persoon gewillig, en in sommige gevalle selís begerig, om die straf op sy daad te aanvaar. Die ongehoorsaamheid waarmee ons dus hier to doen het, is nie ' $n$ universele nie, maar 'n partikuliere verskynsel.

Dit moet ook duidelik wees dat burgerlike ongehoorsaamheid nie alle vorme van ongehoorsaamheid insluit nie. Burgers kan op individuele basis, wette insake spoed oortree, of sekere wette insake finansiële aangeleenthede vanweë eie belang probeer ontduik, of van tyd tot tyd arbeidswette nie gehoorsaam nie. Maar die ongehoorsaamheid waarom dit in burgerlike ongehoorsaamheid gaan, is gemik op politieke wette wat geldig is aangesien dit volgens die prosedure van 'n parlementêre demokrasie tot stand gekom het. Dit gaan dus nie (of nie noodwendig nie) om disrespek vir die regstaat nie, ook nie om ' $n$ verwerping van al die handelinge van die staat nie, maar ten opsigte van bepaalde handelinge is daar ' $n$ morele verpligting om te protesteer. Die ongehoorsaamheid waarom dit hier gaan, kan direk of indirek wees. Die ongehoorsaamheid is direk wanneer die wet wat onregverdig en immoreel beskou word, oortree word. Die wetsoortreding as sodanig word dan as die gewenste oogmerk beskou. Maar dié ongehoorsaamheid kan ook indirek wees waar die effek nie onmiddellik of direk bereik word nie. So word byvoorbeeld geprotesteer teen 'n onregverdige corlog deur te weier om militêre diensplig te verrig.

In aansluiting by die begrip ongehoorsaamheid wil ons ook nog daarop wys dat ongehoorsaamheid in twee gestaltes kan manifesteer: dit kan bloot protes wees teen ' $n$ bepaalde saak, mening of handeling wat dan in die vorm van ' $n$ afkeurende gesindheid, kritiese gesprekke of geskrifte tot openbaring gebring word. Maar ongehoorsaamheid kan ook in verskillende vorms van verset uitgedruk word. Verset gaan verder as protes. Terwyl laasgenoemde ' $n$ meer positiewe benadering aandui, is eersgenoemde negatief; dit wil nie aanvaar nie, maar verwerp; dit wil nie saamwerk nie, maar teenwerk; dit wil nie verstaan nie, maar verander. Op die vraag of daar ook ' $n$ reg van protes en ' $n$ reg van verset bestaan, moet positief geantwoord word. Omdat die mens ' $n$ plig tot gehoorsaamheid - onvoorwaardelike - gehoorsaamheid aan God het, het die mens ook die reg om ongehoorsaam te wees aan en hom selfs te verset teen die ander mens, en elke instelling wat hom tot ongehoorsaamheid aan God wil dwing (vgl Hand 5:29). 
Uiteraard gaan dit vir ons hier nie om alle vorms van protes en verset nie, maar slegs om dié binne staatsverband. Die reg van protes deur die burger teen handelinge van die staat, moet as een van sy basiese regte gehandhaaf en eerbiedig word. Trouens, selfs in 'n noodtoestand moet die reg van protes steeds erken word, en nie effektief na die kategorie van misdade verplaas word nie. Juis in so ' $n$ toestand kan mag baie maklik misbruik word, en kan onreg gepleeg word. In die algemeen moet ons sê dat 'n reg van protes uiteraard verval as die gronde daarvoor, naamlik ongeregtigheid van die staat ontbreek. Dan is dit 'n ongeregverdigde protes.

Ten opsigte van die reg van verset sal 'n drieërlei onderskeiding gemaak moet word: tydelike verset, aktiewe verset en gewelddadige verset. Burgerlike ongehoorsaamheid kan die vorm van tydelike en aktiewe verset aanneem wanneer wetsoortreding daarmee gepaard gaan. Wanneer die verset egter met geweld gevoer word, is dit nie meer burgerlike ongehoorsaamheid nie. Nietemin, omdat burgerlike ongehoorsaamheid log ' $n$ vorm van verset is en nie bloot net 'n protesaksie is nie, is dit nodig om, ook histories, na die beginsel van die reg van verset te kyk.

In Reformatoriese kringe was die algemeen geldende beginsel nog altyd: die owerheid as instelling van God moet gehoorsaam word. Maar as die owerheid só sou optree dat mense gedwing word om deur en in hulle gehoorsaamheid aan die owerheid ongehoorsaam aan God te wees, dan moet die owerheid weerstaan word totdat die reg herstel is. Hierdie toegewing, gebaseer op die Bybelse boodskap dat God eerder gehoorsaam moet word as mense, het nie 'n revolusionêre verandering van die samelewing ingesluit nie, maar het slegs gegaan om ' $n$ regsherstel en ' $n$ terugkeer na gesonde regsverhoudinge. Sowel Calvyn as Luther het hulle baie gereserveerd uitgelaat oor hierdie reg, juis omdat dit so maklik tot onbeheerste geweld kon lei. Maar ten spyte daarvan dat albei tirannie bo anargie verkies het, het hulle tog die reg van verset aanvaar ${ }^{6}$. Omdat die volksmagistrate volgens Calvyn die bevoegdheid gehad het om oor die regeermag van die owerheid toesig te hou, het hulle as mindere owerhede dus ook die reg gehad van verset.

Onderhewig aan die volgende voorwaardes is die reg van verset teen die owerheid toegelaat:

(a) Wanneer die totale lewensomstandighede só ontaard het en menslike verdraagsaamheid en lyding as't ware tot hulle uiterste moontlikhede beproef is, dat die mens nie meer tot eer van God kan leef nie, en gehoorsaamheid aan die owerheid in werklikheid ongehoorsaamheid aan God beteken, het die reg van verset binne die gesigsveld van moontlike handelinge gekom. (b) Maar tot die daadwerklike uitoefening daarvan mag alleen oorgegaan word wanneer alle vorms van samespreking en onderhandelinge beproef is, en onherroeplik nodeloos geblyk het. Met ander woorde, die daad van verset is die allerlaaste middel wat gevolg word in die lang en uitgerekte poging om reg te herstel. (c) Diegene wat hulle verset moet nie net seker wees van wye en sterk steun nie, maar moet ook die potensiaal besit om 'n alternatiewe regering te vorm of te laat vorm. (d) Die moontlikhede van 'n suksesvolle optrede moet goed wees, terwyl die uitvoering met ' $n$ minimum van lewensverlies gepaard moet gaan. (e) Afgesien van ' $n$ duidelike doelstelling met die optrede self, moet die vooruitsig ook goed wees dat die uiteindelike omstandighede ná die verset beter sal wees as die heersende omstandighede vóór dit verset.

Ná hierdie enkele opmerkinge oor die reg van verset, keer ons terug na burgerlike ongehoorsaamheid om meer konkreet na spesifieke kenmerke daarvan te kyk. 


\section{2.. Kenmerke}

Burgerlike ongehoorsaamheid is duidelik die handelinge van meelewende polities aktiewe burgers wie se ideale vir die samelewing, en wie se opvatting van geregtigheid, nie klop met die werklikheid rondom hulle nie. En aangesien hulle nie van plan is om hulle ideale te verander nie, moet die werklikheid verander word. Hulle meelewing sluit ook in en word gestimuleer deur 'n diep gevoel van solidariteit met almal wat ly onder 'n bepaalde politieke bestel.

Burgerlike ongehoorsaamheid word deur sy ondersteuners nie gesien as die faktor wat spanning en stryd in die sameiewing veroorsaak nie, maar as die instrument waardeur dle reeds aanwesige, hoewel verborge, spanning slegs na die oppervlak gebring word, sodat mense dit kan sien, ervaar en daaraan aandag kan gee. Volgens sommige is die situasie van die wêreld tans objektief revolusionêr'. Burgerlike ongehoorsaamheid is wel sterk gefokus op die positiewe waardes van reg en geregtigheid, maar nog sterker figureer die doelwitte van anti-rassisme, anti-apartheid, anti-militarisme en anti-kernenergie.

Burgerlike ongehoorsaamheid is in sy beplanning, bedoeling en voltrekking, ' $n$ oortreding van ' $n$ wet of ' $n$ maatreël van die owerheid en nie bloot kritiek of protes daarteen nie. Onbehae met, of kritiek teen of verskil van ' $n$ bepaalde optrede van die owerheid, kan op verskillende maniere uitgeoefen word, soos deur middel van stemreg, briewe in koerante, protesgeskrifte met handtekeninge, en vergaderings. Dit alles is wettige vorms van protes en geen burgerlike ongehoorsaamheid nie. Laasgenoemde is ' $n$ duidelike en openlike oortreding van 'n wet, ofskoon nie alle wetsoortredinge as burgerlike ongehoorsaamheid aangemerk kan word nie. Wie byvoorbeeld onbewustelik ' $n$ spoedoortreding begaan, pleeg nie burgerlike ongehoorsaamheid nie. Maar wie bewustelik aan stakings en boikotte, optogte en byeenkomstes wat deur die wet verbied word, deelneem, maak hulle aan burgerlike ongehoorsaamheid skuldig. Ofskoon 'n wet oortree word, word die reg nie oortree nie (word beweer) aangesien die wet onwettig is, en dus nie die reg dien nie.

Burgerlike ongehoorsaamheid is ' $n$ handeling gegrond in ' $n$ diepe gewetensoortuiging. "Ek kan nie, en ek mag nie hierdie wet gehoorsaam nie, aangesien my gewete (God) my nie toelaat nie." Hierdie woorde dui op 'n duidelike konfliksituasie waarin enersyds die gewete en/of God teenoor die owerheid andersyds te staan kom, en dan vir eersgenoemde gekies word ${ }^{8}$. Aan burgerlike ongehoorsaamheid lê dus ' $n$ morele oortuiging ten grondslag, en nie kriminele motiewe nie. Daarom het burgerlike ongehoorsaamheid vir hierdie mense ' $n$ roeping en 'n plig geword.

Burgerlike ongehoorsaamheid is as buiteparlementêre aksie, in sy opset en bedoeling nie op wetteloosheid en dus op chaos ingestem nie, en ook nie primêr en in direkte sin op eie belang nie, maar op reg en geregtigheid, en dus op die onregverdigheid van die wet - uiteraard volgens eie, subjektiewe mening ${ }^{9}$.

Burgerlike ongehoorsaamheid as tydelike en/of aktiewe verset is 'n openbare aksie gemik op 'n maksimale hoeveelheid publisiteit om sodoende morele druk uit te oefen, ten einde die owerheid in verleentheid te bring, maar nie die regsorde as sodanig te ondermyn nie. Die finale oogmerk is om verandering teweeg te bring. Pogings om die daad van protes te verberg word beskou as 'n ontduiking van die wet. In die volle aangesig van die wet, word geprotesteer teen die wet of sy onderdele. Geweld word in beginsel afgewys, en ook nie gebruik nie. 
Burgerlike ongehoorsaamheid veronderstel die aanvaarding van en die onderwerping aan die gevolge van juridiese teenaksies deur die owerheid. So word arrestasies byvoorbeeld verwelkom as ' $n$ geleentheid om die saak voor ' $n$ breër publiek te stel en te verdedig.

Burgerlike ongehoorsaamheid dui nie op ' $n$ totale verwerping van alles wat die owerheid doen nie. Met ander woorde waar gehoorsaamheid die reël is, is burgerlike ongehoorsaamheid met betrekking tot 'n bepaalde saak, die uitsondering. Word burgerlike ongehoorsaamheid egter die reël, dit wil sê die permanente lewenspatroon van 'n groep mense, is dit nie meer burgerlike ongehoorsaamheid nie, maar rebellie, opstand en verset teen die gesag van die owerheid as sodanig ${ }^{10}$. Burgerlike ongehoorsaam heid kan alleen voorkom binne die politieke konteks van 'n demokratiese regstaat aangesien dié vorm van protes binne 'n diktatuur lewensgevaarlik sou wees. Alleen die demokrasie veronderstel en het ruimte vir mense om hulle selfstandige morele en politieke oortuiginge uit te spreek.

'n Versigtige en noukeurige analise van bogenoemde kenmerke van burgerlike ongehoorsaamheid laat baie duidelik blyk dat die verskynsel van burgerlike ongehoorsaamheid in 'n bepaalde lewens- en wêreldbeskoulike oortuiging gewortel is en ook daaruit ontspring. Ook hieraan sal ons moet aandag gee, ten einde burgerlike ongehoorsaamheid kontekstueel te kan verstaan en 'n ewewigtige evaluering te kan maak. Uiter aard sal hierdie beskoulike aspekte sekerlik ook as kenmerke gesien kan word. Maar dan is hulle in 'n sekere sin tog anders - dieper en in ' $n$ oorspronkliker sin - as die kenmerke wat ons vroeër weergegee het. Hier het ons meer te doen met die wortels waaruit die verskynsel ontspring en ' $n$ aanduiding van die kragbronne waaruit geleef word.

\section{Beskoulike agtergronde}

Die algemene lewens- en wêreldbeskoulike dampkring wat in direkte en indirekte sin as die geestelike voedingsbron vir die verskynsel van burgerlike ongehoorsaamheid beskou kan word, is ongetwyfeld die historiese proses van sekularisasie maar meer konkreet die standpunt van sekularisme ${ }^{11}$. Op die nuanseverskille en ooreenstemminge tussen sekularisasie en sekularisme gaan ons nie hier in nie. Wat vir ons hier van belang is, is die tipiese geesteshouding van die sterk gesekulariseerde moderne mens: die sentraalstelling van die wêreld en natuurlik ook van die lewe in die wêreld. Dit wil nie sê dat die metafisiese werklikheid heeltemal ontbreek nie; ten minste, dit hoef nie noodwendig die geval te wees nie, maar die fokus het verskuif na die binnewêreldse werklikheid en na die gehalte van 'n binnewêreldse lewe. Met die sentraalstelling van die kosmiese werklikheid gaan as vanself ook gepaard die aksent op die dinamiek van die kosmiese werklikheid. Die werklikheid (en dit geld veral ook die historiese prosesse van sosiale strukturering) is nie 'n onveranderbare, altyd in homself gelykblywende gegewe nie, maar ' $n$ veranderbare werklikheid. Opgeneem in ' $n$ voortdurende proses van verandering, word die werklikheid soos klei in die hande van die moderne, deur die ontwikkeling van die wetenskap en tegniek, versterkte kragmens. Die sentraalstelling van die kosmiese werklikheid het as noodsaaklike teenpool die sentraalstelling ook van die mens; van sy posisie in die wêreld, van sy krag ten opsigte van die wêreld, en van sy verantwoordelikheid teenoor die wêreld. Met die indringende krag van sy intellektuele denke ontrafel die mens die diepste en 
mees verborge geheime van die natuur, hy dwing hom in sy diens en maak hom ondergeskik aan sy kragte. Bewus van sy unieke posisie en besondere vermoë, gekenmerk deur 'n verskerpte morele bewussyn en ' $n$ besondere sensitiwiteit vir, en 'n oortuiging van die basiese reg op, 'n eie gewetensoordeel, is die vryheid tot eie, selfstandige toetsing en opweeg van alles, vir hierdie mens van beslissende betekenis. Ontsag vir gesag wat van buite kom en eisend teenoor die mens gestel word, moet swig voor die gesag wat outonoom uit die selfbeslissende en selfnormerende enkeling opkom. Daarom is die samelewing nie soseer ' $n$ organiese geheel nie, maar eerder ' $n$ meganiese geheel wat uit min of meer selfstandige onderdele opgebou is waarin die individuele lede ' $n$ beslissende rol speel.

Teen die agtergrond van hierdie algemene geestesdampkring - voorberei deur die historiese proses van sekularisasie - is dit enigsins te begryp as ons nou sê dat burgerlike ongehoorsaamheid 'n sosiale verskynsel is wat sterk intellektualisties en moralisties is; individualisties en aktivisties, pluralisties en anargisties.

Eersgenoemde twee kom saam waarskynlik die beste tot uitdrukking in die oortuiging dat dit vir ' $n$ regstaat kenmerkend is dat die beleid van ' $n$ regering en dus ook sy wette, in ooreenstemming moet wees met die regsbesef van die burgers van die land. Langs die weg van rasionele prosesse van toetsing en vergelyking on uitgaande van ten minste sommige van die burgers se opvatting van die etiese en die reg as die laaste norm word dan vasgestel of die staat ten opsigte van dié bepaalde aangeleentheid ' $n$ regstaat is al dan nie. Die individualistiese en aktivistiese inslag is veral geleë in die feit dat slegs bepaalde burgers - en nie alle burgers nie - tot die oortuiging kom van die onreg van sekere wette of dele van wette, en dan moreel verplig voel om in verband daarmee handelend op te tree, in die oortuiging (uiteraard) dat hulle dit kán verander. $V a n$ ' $n$ universele geldigheid ten opsigte van die reg kom in burgerlike ongehoorsaamheid weinig tereg, aangesien dit enkele individue is wat namens ' $n$ bepaalde groep in die samelewing optree, met die veronderstelling dat dit in ' $n$ ander groep anders daaraan kan toegaan. Hierdie pluralistiese beskouing kan maklik lei tot, en herberg trouens in homself die prinsipiële moontlikheid van anargisme. Daarmee beweer ons nie dat anargisme, wat basies teen die staatsbestel as sodanig gerig is, identies is met burgerlike ongehoorsaamheid nie. Maar dit kan ten minste histories bewys word dat burgerlike ongehoorsaamheid met sterk anargistiese oortuigings deurtrek is, terwyl burgerlike ongehoorsaamheid prinsipieel nie sterk weerstand teen anargisme kan bied nie.

Ondersteuners van burgerlike ongehoorsaamheid het bepaalde probleme met die wyse waarop die beginsel van demokrasie in die huidige parlementêre stelsel toegepas en uitgewerk word. Om dit konkreet te formuleer: gee die parlementêre stelsel voldoende uitdrukking aan die ideaal van die demokrasie? Laasgenoemde is immers 'n regering deur die volk, met ander woorde, 'n absolute volksoewereiniteit. Maar dit impliseer nie 'n vasstaande, afgeslote strukturele gegewe nie, want die gelyke deelname van almal kan nie langs dié weg bereik word nie, en ewe min kan alle beskouings bevredigend geakkommodeer word. Daarom moet die begrip demokrasie verruim word. Dit mag nie as 'n toestand van vaste reëls en strukture gesien word nie, maar as 'n dinamiese proses. Die dinamiek in die gebeure van demokratisering laat die prosesmatige verloop daarvan nooit tot 'n afgeronde gegewe stol nie, maar hou dit steeds as ' $n$ vloeiende proses aan die gang. En juis in hierdie proses van voortgaande kollektiewe demokratisering wil die ondersteuners aan die verskynsel van burgerlike 
ongehoorsaamheid sy regmatige plek en funksie toeken. Daarom bly die vraag: kan hierdie proses van demokratisering in die gegewe parlementêre stelsel beliggaam word? Die parlementêre demokrasie is immers 'n regering deur die meerderheid van die bevolking, dog nie deur die hele bevolking nie. Daarby kom nog dat die verteenwoordigers in die parlement nie 'n vrye keuse het nie, maar van hulle party 'n mandaat $k r y$ ten opsigte van hulle optrede en stemming. Hierdie partydwang maak van demokrasie 'n bespotting. In elk geval is dit duidelik dat die standpunte van die minderheid nie in aanmerking geneem kan word nie, aangesien die meerderheid op ' $n$ tipies outokratiese wyse optree. Die meerderheidsbeginsel is ongetwyfeld vir die demokrasie belangrik, want dit voorkom die diktatuur van die minderheid. Maar dit beteken nie dat die waarheid vasgestel word met behulp van die meerderheidsbeginsel nie, of dat die meerderheid kan doen wat hy wil en byvoorbeeld fundamentele menseregte aantas nie - dan het ons 'n diktatuur van die meerderheid, en daarmee is demokrasie self wesenlik aangetas. 'n Goeie demokratiese beginsel is dus dat die meerderheid rekening moet hou met die minderheid. Die vraag is egter: hoe moet dit gedoen word? Ondersteuners van burgerlike ongehoorsaamheidsaksies onderskryf enersyds die prinsipiële korrektheid van demokrasie en andersyds die noodsaaklikheid van vaste ordes en goed omskrewe parlementêre prosedures; ware demokrasie is egter veel ruimer as net laasgenoemde. Anders gesê: reg en geregtigheid word nie net langs goed omskrewe, neergelegde parlementêre demokratiese prosedures gedien nie. Ook buite die parlement word die reg gesoek en gedien deur hulle wat weliswaar nie amptelik verkies is om wette te maak nie, maar wat wel deur hulle gewete geroep is om aan die besluitnemingsprosesse, ook buite die parlement deel te neem en om die gemaakte wette aan die norm van die reg te toets. Ook wanneer aan hierdie toetsing in die vorm van burgerlike ongehoorsaamheid uiting gegee word, is die bedoeling nie om ' $n$ bedreiging vir of uitholling van die demokrasie te wees nie, maar om juis ' $n$ uitbouing en 'n versterking daarvan te bied. Langs die weg van burgerlike ongehoorsaamheid en die suksesse wat daarmee alreeds bereik is, kan 'n bydrae gelewer word tot die innerlike aanvaarding van wette en maatreëls, en kan 'n vertrouensverhouding tussen burgers en regering tot stand kom.

Hierdie vorm van verset teen meerderheidsbeslissings gee direk aanleiding tot die weeg van stemme, naas en bo die blote tel van stemme. Ondersteuners van burgerlike ongehoorsaamheid beweer dan ook dat, ten spyte van die demokratiese inslag van die grondwette en konstitusie van die meeste lande, daar ten minste één basiese reg ontbreek, en dit is die reg op en dus die vryheid tot deelname aan burgerlike ongehoorsaamheid. Tegelykertyd word egter erken dat dit waarskynlik ook deur geen owerheid toegelaat sal word nie, aangesien die argument sal wees dat daar voldoende grondwetlik gewaarborgde moontlikhede vir politieke protes bestaan.

Ondersteuners van burgerlike ongehoorsaamheid het ook ten opsigte van die staat 'n eie mening. Op slegs twee aspekte vestig ons die aandag - die eerste 'n prinsipiële en die tweede 'n meer praktiese aangeleentheid. Wat die eerste betref: beskouinge wat in hierdie kringe verdedig word, sluit meer aan by die opvatting dat die staat op 'n sosiale kontrak berus as dat die staat ' $n$ instelling van God is. Die staat is dus min of meer die resultaat van 'n sosiale kontrak wat mense met mekaar aangegaan het. Die burgers het die staat as 'n regeringsvorm gekies, en daarom bestaan daar ' $n$ intieme band tussen burgers en staat. Eintlik so intiem dat met reg deur die burgers gesê kan word: "die staat - dit is ons". 
Omdat die staat dus kragtens ' $n$ ordereëling van vry mense bestaan wat oor regte beskik en aan die staat gesag toeken, ten einde hulle regte en vryhede te beskerm en to bevorder, daarom het die onderdane ook die reg om die staat se gebruik van gesag te toets, te kritiseer en as dit nodig is, ook te weerspreek. Hierdie toetsingsreg kom nie net enkele bevoorregte uitverkorenes toe nie, maar alle onderdane wat volledige burgerskap het.

'n Tweede aspek van hierdie prinsipiële beskouing is daarin geleë dat die kontrolering van die owerheidsoptrede nie net op die beskouing van die kontrakteorie ten opsigte van die staat gebaseer word nie. Ook wanneer die owerheid as 'n Goddelike instelling aanvaar word, maar hy nie aan God gehoorsaam is nie, met ander woorde as die staat nie of nie meer ' $n$ regstaat is nie, maar 'n magstaat, het die burgers, binne en buite die parlement, die reg om die staatsoptrede te kritiseer en te probeer korrigeer.

Met hierdie opmerking het ons dan ook by die tweede, en meer praktiese aspek van die standpunt van die ondersteuners van burgerlike ongehoorsaamheid gekom. Hulle beweer naam lik dat die Suid-Afrikaanse staat nie 'n regstaat is nie, maar 'n magstaat; in eersgenoemde reël reg die mag, in laasgenoemde bepaal mag die reg, maar daarmee word die reg dan ook vernietig. In die Suid-Afrikaanse magstaat word die mees primêre sosiaal-etiese beginsels nie gehandhaaf nie: mense is en word beroof van hulle wettige eiendom; basiese regte soos stemreg mag hulle nie uitoefen nie; mense se lewens word nie beskerm nie maar bedreig met aanhouding sonder verhoor; die waarheid oor toestande in die land word nie meegedeel nie en die agteruitgang in verhoudinge tussen groepe word verswyg, swartmense word op verskillende gebiede, soos in onderwys en behuising, benadeel en blankes bevoordeel; daar is geen gelykheid voor die wet en geen gelykheid in regstoepassing nie.

In die lig van hierdie en ander beskuldigings word die besware teen die Suid-Afrikaanse regering op twee punte saamgetrek: die wettigheid van ' $n$ regering wat nie deur die hele bevolking nie, maar deur 'n klein deel daarvan gekies is, word ernstig bevraagteken en vervolgens word ook die moraliteit van die regering se handelinge en met name die wette wat die regering maak, bevraagteken. Wie aan so 'n regering gehoorsaam is, werk mee aan die uitholling van die regstaat en dra by tot die bestendiging van die magstaat. Daarom is die roeping van burgers in so ' $\mathrm{n}$ krisissituasie die van ongehoorsaamheid, en dié ongehoorsaamheid is in werklikheid 'n positiewe bydrae tot die gebeure in die regstaat - want die regstaat bly bestaan slegs so lank as wat alle burgers gesamentlik verantwoordelikheid aanvaar vir die instandhouding daarvan. Die gevaar van die bestendiging van die magstaat word nog groter, so ook die vermindering van die kritiese toetsing van die regverdigheidsgehalte van die owerheidshandelinge en nog makliker die verabsolutering van die staat, as nog toegevoeg word dat die owerheid in diens van God staan. Dan word dit moontlik dat selfs die grofste onreg van owerheidsweë aanvaar en met Goddelike sanksie beklee word.

Die voorafgaande opmerkings was daarop gemik om 'n duidelike beeld van die verskynsel van burgerlike ongehoorsaamheid te probeer teken. Intussen het dit egter tyd geword om 'n kritiese afstand van die verskynsel te neem en tot 'n etiese evaluering daarvan te geraak. Hieruit sal ook enkele positiewe riglyne voortvloei. 


\section{Kritiese evaluering}

Die diepste kern van burgerlike ongehoorsaamheid is die feit dat hier ' $n$ aksie van verset in woord en daad gevoer word en wel op so 'n wyse dat dit nie binne die ruimte van die wet en wel in gehoorsaamheid aan die eise van die wet plaasvind nie, maar juis op so ' $n$ wyse dat dit teen die wet ingaan, en onvermydelik maar doelbewus, op wetsoortreding uitloop. Oor die reg van ongehoorsaamheid, tot selfs by die punt van wetsoortreding, die voorwaardes daarvoor en die omstandighede waaronder dit mag plaasvind, handel ons nie in hierdie paragraaf nie. Dit gaan ons later aan die orde stel. Hier wil ons net wys op enkele gevare van en die besware teen burgerlike ongehoorsaamheid.

Wat daar ook al deur ondersteuners van burgerlike ongehoorsaamheid oor die demokrasie gesê word, onder meer dat hulle dit nie wil ondermyn nie, maar juis wil uitbrei, dat hulle nie teen demokrasie is nie, maar daarvoor, het ons ten diepste hier met ' $n$ anti-demokratiese verskynsel te doen. Die standpunt wat hier verdedig word, en die optrede wat hier regverdig word, kom in beginsel daarop neer dat demokrasie nie ' $n$ voldoende meganisme bied vir die uitoefening van die mens se basiese politieke regte nie. Meer nog: as aksie van ' $n$ minderheid wat die meerderheid probeer manipuleer en sodoende ' $n$ verskuiwing van aksent probeer bewerkstellig van die meerderheid na die minderheid, is wat hier in burgerlike ongehoorsaamheid gesê en gedoen word, inderdaad 'n positiewe ondergrawing en uitholling van demokrasie, en daarmee tegelyk 'n pleidooi vir die devaluering van wettige gesag. En waar die stelsel van demokrasie en die gesag aangetas word, kan ' $n$ toestand van anargie ontstaan wat op sy beurt voedend kan inwerk op die skepping of versterking van 'n magstaat wat weer die dreigende gevaar van ' $n$ polisiestaat ' $n$ reële werklikheid maak. Maar daardeur word ook die regstaat ondermyn - en so werk burgerlike ongehoorsaamheid teenproduktief aangesien die resultaat juis dit is waarteen so ernstig betoog word.

Die standpunt dat burgerlike ongehoorsaamheid anti-demokraties en daarom nie aanvaarbaar is nie, kan die indruk wek dat demokrasie die norm is vir die etiese aanvaarbaarheid al dan nie van 'n bepaalde verskynsel. Demokrasie soos beliggaam in die bekende parlementêre regeringstelsel is sekerlik nie die onverbeterlike finale norm nie. Baie kom nog hierin te kort, en baie moet nog hieraan verander word ten einde dit ' $n$ bevredigende stelsel te maak vir die uitdrukking en die beskerming van die mens se sosiale en politieke grondregte. Só sou byvoorbeeld, om die inspraak van meer burgers te verseker en ' $n$ tirannie van die meerderheid oor die minderheid te voorkom en teen te werk, meer gebruik gemaak kon word van die beginsel van referendums. Dit wil sê: sekere kategorieë van wette wat deur die regering gemaak word, kan deur middel van nasionale referendums getoets word en in werking gestel word wanneer dit die ondersteuning van die meerderheid burgers geniet. Groter inspraak kan groter lojaliteit en selfs groter gehoorsaamheid tot gevolg hê. Vervolgens sou ook ' $n$ groter desentralisering van die regering oorweeg kan word. Dit is ' $n$ feit dat 'n hoogs gesentraliseerde regeringstelsel aanleiding gee tot outokratiese optrede en dat dit lei tot misnoeë en maklik uitloop op aksies van burgerlike ongehoorsaamheid. Deur beperking van die sentrale regering en die oordra van meer funksies na die streeks- en plaaslike owerhede, kan groter inspraak aan meer mense gegee word, maar daarmee kan ook rekening gehou word met die verskeidenheid van die bevolking $^{12}$. Wat ons wil sê is dat ' $n$ hoë graad van desentralisasie in regeringsfunksies 
bevorderlik is vir die inhoudelike verbreding en verdieping van die demokrasie, en dat die behoefte aan dèsentralisering groter word, hoe groter die heterogene samestelling van die samelewing blyk te wees.

Inderdaad, die parlementêre demokrasie is nie die laaste norm nie. Maar burgerlike ongehoorsaamheid in teorie en praktyk, skakel homself uit die demokrasieprosesse uit waar burgers die geleentheid kry om hulle politieke regte uit te oefen en waar hulle deur middel van gereelde verkiesings, veranderinge teweeg kan bring. Die alternatiewe, of uitgebreide vorms van verandering en van protes soos deur burgerlike ongehoorsames voorgestel word, is basies anti-demokraties, en maak 'n parlementêre regeringstelsel met bindende regeringsbesluite deur wettige volksverteenwoordigers, in beginsel onmoontlik. Burgerlike ongehoorsaamheid kan dan ook gesien, en veroordeel word as die permanente strategie van die minderheid teenoor die meerderheid wat ' $n$ bevoorregte posisie beklee en dit wil behou, of as wapen van die permanente verloorders. In 'n demokratiese regstaat waar dit ten diepste gaan om die reg - die reg wat ' $n$ deur God gewilde inherente gerigtheid op die humaniteit vertoon (Calvyn) - word van alle burgers gehoorsaamheid gevra, omdat daardeur ook ruimte vir ander gegun word. Maar waar daar nie gehoorsaamheid betoon word nie, word die regte van ander en hulle vryheid ernstig bedreig.

Burgerlike ongehoorsaamheid is egter nie net anti-demokraties nie, dit is ook gevaarlik subjektivisties.

Natuurlik het die gewete, en gewetensoortuiging, 'n plek in die bepaling van ' $n$ mens se handelinge. Maar is ' $n$ beroep op die gewete sonder behoorlik verifieerbare gronde, en op basis van die veronderstelling dat die gewetensoortuiging van die meerderheid van die parlementêre volksverteenwoordigers op hierdie besondere punt dwaal, voldoende motivering vir die regverdiging van aksies van burgerlike ongehoorsaamheid? Morele of gewetensgronde is meestal subjektief, arbitrêr, onoortuigend en niekontroleerbaar. Daarom is dade sekerlik nie outomaties geregverdig nét omdat dit op aandrang van die gewete gedoen word nie. Juis vanweë die kritiese afstand van en verset teen die demokratiese prosesse, onttrek die ondersteuners van burgerlike ongehoorsaamheid hulle van die so nodige kollektiewe beheer wat in die demokrasie ingebou is. Eintlik moet dit andersom gestel word: juis vanweë ' $n$ baie sterk individualisties-subjektivistiese liberalistiese lewens-en wêreldbeskoulike siening, kan hulle nie, en wil hulle nie, die sosiale korrektief op die grondslae van hulle handelinge aanvaar nie.

Daarom kan die gronde vir dergelike aksies nooit die massa tot ' $n$ eenheid saamsnoer nie, maar kan dit hoogstens bepaalde groepe inspireer. Die onvermydelike gevolg hiervan is polarisasie en spanning. Trouens, burgerlike ongehoorsaamheid begin en eindig met polarisasie. Hier moet gemeenskapsbelange wyk voor en ondergeskik gemaak word aan groepsbelange. Is hierdie individualisties-subjektivistiese ingesteldheid nie ook die oorsaak daarvan dat die aksies van burgerlike ongehoorsaamheid dikwels die indruk laat van 'n naïwe utopisties-aktivistiese maatskappybeeld met ' $n$ ernstige gebrek aan fundamentele insig in, kennis van, en verantwoordelikheid vir die langsame en moeisame prosesse van verandering en verbetering van die samelewing nie?

Ten derde:ten spyte van 'n duidelike afkeer van geweld, is die gewelddadige potensiaal van alle aksies van burgerlike ongehoorsaamheid nie denkbeeldig en bloot ' $n$ teoretiese moontlikheid nie ${ }^{13}$. Wat rustig en kalm deur die georganiseerde groepe begin 
word, kan die weg open vir nouliks beheerbare vorms van massahisterie wat nie net gevoelens van geweld ontlok en stimuleer nie, maar ook maklik kan oorgaan in dade van terreur en verwoesting. Daardeur kan die politieke en sosiaal-maatskaplike strukture ondermyn word, die totale orde vernietig word en die administrasie tot stilstand gedwing word. So word die oorspronklike oogmerk van groter geregtigheid verongeluk en verder wegbeweeg van 'n regstaat.

Uiteraard kan nog veel meer kritiek teen burgerlike ongehoorsaamheid uitgespreek word. Ons volstaan egter met hierdie enkele punte én vra onmiddellik die vraag: beteken die voorafgaande opmerkings nou dat burgerlike ongehoorsaamheid nooit onder enige omstandighede mag voorkom nie? Anders geformuleer, maar basies nog dieselfde: moet die staat in alles wat hy doen, onvoorwaardelik gehoorsaam word? Hieraan wil ons nou aandag gee.

\section{Positiewe riglyne}

5.1 Vir die Christelike etiek is dit duidelik dat onvoorwaardelike gehoorsaamheid aan die handelinge van die owerheid - wat die funksies van die staat uitvoer - nie gegee kan word nie. Die owerheid bestaan uit sondige mense, en ofskoon God hulle in sy diens gebruik en hulle met gesag toerus, beteken dit vir geen oomblik dat hulle nie foute kan maak nie. Besluite kan geneem word en wette kan gemaak word wat nie met Gods Woord ooreenstem nie, en selfs daarteen ingaan. Daarby kom nog dat die mens God alleen onvoorwaardelik mag gehoorsaam. Die Skrif self sê: "n mens moet eerder aan God gehoorsaam wees as aan mense!" (Hand 5:29). Aan die ander kant is dit ook waar, onder meer in die lig van Romeine 13:1-7 en 1 Petrus 2:13-17 (vgl ook Matt 22:15-22) dat die owerheid gehoorsaam móét word. Hoewel Christene dus 'n dubbele lojaliteit het, en wel teenoor God én die staat, beteken dit vir geen oomblik dat ons hier met 'n gelykwaardige lojaliteit te doen het nie. Terwyl die gehoorsaamheid aan God absoluut en onvoorwaardelik is, is die gehoorsaamheid aan die aardse owerheid nie absoluut nie, maar voorwaardelik ${ }^{14}$. Dit beteken dus dat die staat op ' $n$ bepaalde oomblik, deur sy optrede, sy reg op gehoorsaamheid kan verbeur.

Waar die owerheidsbepalinge nie in ooreenstemming is met Gods Woord nie, die owerheid nie regeer volgens die geldende reëls van die konstitusionele demokrasie nie, die reg nie gehandhaal word nie, die regbank nie betroubaar is nie, minderhede uitgebuit en onderdruk word, kortom, wanneer die lewe onmenslik en ondraaglik geword het, het die burgers die reg van verset.

5.2 Ons het dit reeds gesê: burgerlike ongehoorsaamheid is 'n sekere vorm van verset, en mits dit aan sekere voorwaardes voldoen, sal ons, anders as wat ander oordeel ${ }^{15}$ tog van 'n reg en selfs van 'n plig tot burgerlike ongehoorsaamheid moet praat. Waarom selfs van 'n plig tot burgerlike ongehoorsaamheid? En ons antwoord: as die eer van God op die spel is omdat die reg geskend is, impliseer die reg op ongehoorsaamheid in beginsel tegelyk 'n plig op ongehoorsaamheid 
- die mens het immers nie net 'n plig teenoor sy medemens nie, maar ook teenoor die staat. Dit wil egter nie sê dat die reg tot ongehoorsaamheid outomaties ook 'n plig tot ongehoorsaamheid móét word nie. Dit kan immers gebeur dat van aktiewe optrede, tydelik of selfs permanent afgesien word, aangesien die gevolge van so 'n negatiewe aard kan wees dat dit die saak skade kan doen en moontlik selfs kan verongeluk.

5.3 Van die belangrikste voorwaardes alvorens ons van 'n onvervreembare reg en plig tot burgerlike ongehoorsaamheid kan praat, is sekerlik die volgende:

5.3.1 Waar 'n voortgesette optrede of beslissing van die owerheid so duidelik teen Gods Woord ingaan dat gehoorsaamheid daaraan duidelik ongehoorsaamheid aan God sou beteken, het burgerlike ongehoorsaamheid ' $n$ oorweging van moontlike optrede geword ${ }^{16}$.

5.3.2 Waarom word die daad van burgerlike ongehoorsaamheid in die bogenoemde omstandighede nie as ' $n$ vanselfsprekende en outomatiese werklikheid voorgestel nie? Omdat ons, juis in ons tyd met sy hoogbloei van menslike prestasie en aktivisme, van ongebreidelde begeerte na sukses-kultuur en vurige aandrang tot aksie-kultuur, die morele waarde van die gewilligheid om te ly, wil beklemtoon. Lyding en vervolging behoort immers tot die simboliese tekens van die naderende einde waarna die Christen reikhalsend uitsien; meer nog, midde-in 'n versekulariseerde een-dimensionele wêreld, is dit tekens ook van transendensie: ter wille van die saak van God word lyding verduur en vervolging deur$\operatorname{staan}^{17}$.

5.3.3 Maar laat ons ook byvoeg dat nie net gewilligheid tot lyding en vervolging tekens van transendensie is nie; ook bereidheid tot dapper protes - eweneens ter wille van die saak van God - deurbreek die geslote immanentisme. Daarom sal dit in 'n sekere stadium tot die daad móét oorgaan.

5.3.4 Die daad waarom dit hier dan allereers gaan - gebore as't ware uit, en vrug van en gelouter deur die geestelike ryping in die proses van lyding en vervolging - is dié van onderhandeling en samespreking. Die woord moet die daad voorafgaan. Die weg van die herstel van die geskonde reg, begin met die woord, en gaan met die woord voort, solank daar na die woord geluister word en sinvol en hoopgewend op die woord geantwoord word. Eers wanneer daar stilswye ervaar word, en die hoop nie in aanskoue oorgegaan het nie, volg die daad van ongehoorsaamheid. Met ander woorde, burgerlike ongehoorsaamheid is die laaste middel wat in hoë uitsondering, nadat alle ander wettige middele misluk het, aangewend word om in 'n demokratiese regstaat strukturele onvolkomenhede te probeer verbeter. Maar dan ook omgekeerd: solank as wat daar nog 
moontlikhede bestaan vir en gewilligheid tot onderhandeling, solank is burgerlike ongehoorsaamheid eties nie aanvaarbaar nie.

5.3.5 Binne die basiese gemeenskaplike beginselraamwerk van Christelike waardes en van die demokrasie waarvan die staat hom bedien, funksioneer die burgerlike ongehoorsaamheid as ' $n$ morele appèl op die owerheid. Daarmee is duidelik gesê dat revolusionêre kwaliteite soos die omverwerping van die staat en die ontwrigting van die samelewing nie mag voorkom nie. Ontbreek eersgenoemde voorwaarde het ons nie meer met burgerlike ongehoorsaamheid te doen nie. Om 'n etiese voorbeeld te gee: As die staat ' $n$ huwelik as ' $n$ heteroseksuele verbintenis van twee mense sien, kan daar nie langs die weg van burgerlike ongehoorsaamheid vir homoseksuele verbintenisse geagiteer word nie. En 'n juridiese voorbeeld: terwyl die staat belasting moet invorder om sy funksie as staat te kan uitvoer, kan daar nie vir die afskaffing van belasting betoog word nie. Waar die gevalle wél voorkom, sal die staat dit as 'n direkte bedreiging van die regsorde moet sien; dit ook in dié lig moet beoordeel en dienooreenkomstig optree.

5.3.6 Uiteraard moet die aksie voortspruit uit die eerlike oortuiging dat dit wat as doelwit beoog word ' $n$ groter beliggaming is vir, en 'n duideliker uitdrukking is van reg en geregtigheid en daarom beter en wensliker vir die samelewing is, as die status quo.

5.3.7 Burgerlike ongehoorsaamheid verloor sy geloofwaardigheid en boet sy etiese kwaliteit in, as dit die indruk wek dat groepsbelange gedien word. Waar byvoorbeeld teen diskriminasie en uitbuiting betoog word, en net slagoffers daarvan en nie ook bevoorregtes nie, neem deel, is dit eties bedenklik.

5.3.8 Die praktiese haalbaarheid van die voorgestelde verandering, met ander woorde, die vraag of dit moontlik is vir die owerheid om die verandering teweeg te bring, speel sekerlik ook ' $n$ rol. 'n Aandrang op die prakties onmoontlike kan onnodige en selfs gevaarlike polarisasie veroorsaak.

5.3.9 Die aksie van burgerlike ongehoorsaamheid mag diegene wat nie daarby betrokke is nie, geen leed veroorsaak, nadelig tref en uiteraard nie onder morele druk plaas om mee te doen nie.

5.3.10 Van die grootste belang is die gesindheid van waaruit en waarmee die aksie van burgerlike ongehoorsaamheid geloods word. As dit byvoorbeeld gepaard gaan met dreigemente om tot geweld oor te gaan as daar nie onmiddellik aan die versoeke gehoor gegee word nie, kan ernstige konfliksituasies geskep word. Eweneens sal die ondersteuners van burgerlike ongehoorsaamheid op elke 
teken van begrip en gewilligheid om op die voorgelegde versoeke in te gaan, simpatiek moet reageer. Selfs die geringste hervorming deur die owerheid sal positief verwelkom en samewerking sal gegee moet word ${ }^{18}$.

5.3.11 Laat ons ten slotte ook daarop wys dat dit nie die taak van die kerk is om self aktief aan enige aksie van burgerlike ongehoorsaamheid deel te neem nie ${ }^{19}$. Getroue vervulling van die profetiese funksie van die kerk sal hom daartoe bring om alle onreg in die samelewing aan te wys, én om uiteraard ook die verskynsel van burgerlike ongehoorsaamheid eties te evalueer en prinsipiële leiding te gee. Maar selfs wanneer die kerk hom daaroor positief uitlaat, mag die kerk nie self daaraan deelneem nie.

Nog 'n laaste opmerking moet gemaak word. Die etiese aanvaarbaarheid van hierdie verskynsel - onder bepaalde voorwaardes - en die feit dat die owerheid oorweging sal wil skenk aan die meriete van die versoeke, ontneem in geen opsig die owerheid sy taak om met verantwoordelikheid te regeer nie. En dit sluit vanselfsprekend in om teen almal wat die wet verbreek, dus ook teen burgerlike ongehoorsames, dienooreenkomstig, dit wil sê met inhegtenisname, veroordeling en straf, op te tree. Enige afwyking of opskorting hiervan sou nie net onregmatige optrede beteken nie, maar sou die owerheid ook in ' $n$ onmoontlike posisie van afdreiging plaas. En dit mag ' $n$ owerheid nooit toelaat nie. Die beginsel is immers dat die basiese taak en roeping van die staat nooit verander nie, selfs nie in 'n noodtoestand nie.

\section{NOTAS}

1. Die term "burgerlike ongehoorsaamheid" dateer waarskynlik eers uit die jaar 1848 toe HD Thoreau 'n lesing gehou het oor burgerlike ongehoorsaamheid onder die titel "On the Relation of the Individual to the State". Hierin het hy sy voortgesette weiering om staatsbelasting te betaal, en wat in sy arrestasie en tronkstral geëindig het, geregverdig (vgl HA Bedan [red], Civil Disobedience, New York 1969, 15). Vgl J Douma, Politieke Verantwoordelijkheid, Kampen 1984, 176; A de Quervain, Ethik, 2/1, 240 e.v.; RT Hall, The morality of Civil Disobedience, New York 1971, 13 e.v. Volgens Herbert Marcuse behoort burgerlike ongehoorsaamheid tot die oudste en heiligste elemente van die Westerse beskawing, en dit omdat die bestaande die reg besit om die grense van die legaliteit te bepaal ( $P$ sychoanalyse en Politiek, Amsterdam 1968, 72-73).

2. J Douma maak onderskeid tussen ongehoorsaamheid en burgerlike ongehoorsaamheid. Die genoemde Bybelse voorbeelde is volgens hom wel gewettigde ongehoorsaamheid, maar nie burgerlike ongehoorsaamheid nie. Hy meen dat Christene hulle nooit mag skuldig maak aan "illegale activiteit in de manier van hun protesteren" (Politieke Verantwoordelijkheid, Kampen 1984, 192).

3. Vgl. G Holdijk, Christenen en Burgerlijke Ongehoorzaamheid, 's-Gravenhage 1985, 34.

4. Vgl o.a. DA du Toit (samesteller), Staatsgesag en Burgerlike Ongehoorsaamheid, Kaapstad 1987, 8 en RM Momboisse, Blueprint of Revolution, Illinois 1970, 217 e.v.

"Onder burgerlike ongehoorsaamheid kunnen we verstaan dat demonstratiewe optreden 
dat bewust de wet schendt om op dwingende - zij het geweldloos bedoelde - wijze verandering in een wet of maatregel van de owerheid tot stand te brengen" ( $\mathrm{J}$ Douma, Politieke Verantwoordelikheid Kampen 1984, 177). G Manenschijn gee die volgende definisie: "Burgerlijke ongehoorzaamheid is een bewuste, publieke, geweldloze daad van wetsovertreding, met de bedoeling een verandering tot stand te brengen in een wet, die als onrechtvaardig en/of immoreel wordt envaren" (Burgerlijke Ongehoorzaamheid, Over Grenzen aan Politieke Gehoorzaamheid in een Democratische Rechts-en Verzorgingsstaat, Baarn 1984, 44). Gandhi het burgerlike ongehoorsaamheid omskryf as die "necessary resistance a good person must give to an evil government or law" (Richard K Taylor, in: Ina Wallis (ed.). The Rise of Christian Conscience, San Francisco 1987, 252). "Civil disobedience is disobedience which is 'passive', 'nonviolent' 'courteous' 'not uncivil"' (H A Bedan (ed), Civil Disobedience, New York 1969, 19).

5. "For the overriding aim of those who engage in civil disobedience is to make an effective protest to open grave issues to public debate, to register deep concern and vehement objection" (Carl Cohen, in: HA Bedau (ed), Civil Disobedience. Theory and Practice, New York 1969, 176

6. Luther het hieroor gehandel in sy geskrif: Ob Kriegsleute auch in seligem Stande sein Können (1526) en Calvyn in sy Inst. IV/20, Opera (CA 49) 250, en Opera 52 (CA 80) 267. Vgl J Douma, Politieke Verantwoordelijkheid, 13 e.v.). Die Hugenoteskrywers het in drie geskrifte hulle oor die reg van verset verantwoord. In die Vindiciae contra Tyrrannos (1579) word die volgende vier vrae gestel: (a) Is onderdane verplig om 'n prins te gehoorsaam as hy iets beveel wat teen die wet van God ingaan? (b) Is dit veroorloof om in verset te kom teen 'n prins wat die wet van God oortree of die kerk ruineer? Indien wel, wie mag hom verset en in watter mate is dit wettig? (c) Is dit veroorloof om 'n prins te weerstaan wat 'n staat onderdruk en ruineer? Hoe ver mag sodanige verset strek? Wie mag in verset kom? Hoedanig moet die verset wees en volgens watter wet of reg geskied dit? (d) Mag naburige prinse en state hulp verleen aan hulle wat vervolg word ter wille van die ware religie of wat verdruk word deur opsigtelike tirannie? Al drie die geskrifte erken die reg van verset, maar wil niks weet van revolusionêre verset van die volk teen die owerheid nie. Ten opsigte van die uitspraak, "elkeen mag 'n tiran vermoor" merk Geesink op: "in den tijd der Reformatie achten velen in de Christelijke wêreld den tyrannen-moord voor zich absoluut ongeoorloofd" (Geref Etiek, deel 2, p. 386). Die Kairos-dokument pleit vir die enigste moontlike oplossing in Suid-Afrika en dit is die vervanging van die huidige regering (1988) deur ' $n$ ander. Maar daarvoor moet ook nie-demokratiese, buite-parlementêre metodes gebruik word. Selfs die kerk moet daarvoor ingespan word. Nie alleen moet die kerk aksies soos boikotte en stakings steun nie, die kerk moet ook sorg dat sy programme nie in stryd kom met daardie politieke organisasies wat die ware besware en eise van mense verteenwoordig nie (Kajros, p. 19,21,23). Met reg merk P Coertzen op: "Hierdie oproep tot revolusie en alles wat daarmee saamhang, staan in skrille kontras met die gereformeerde belydenisskrifte se verwerping van revolusie" ("Burgerlike ongehoorsaamheid: 'n Kerkhistoriese Perspektief", in: DA du Toit (samesteller), Staatsgesag en Burgerlike Ongehoorsaamheid, Kaapstad, (1987, p 66). Vgl ook Walter Kreck, Grundfragen christlicher Ethik, p 327 e.v.

7. Vgl ML King, Jr., "Letter from Birmingham City Jail", in: H A Bedau (ed.), Civil Disobedience, Theory and Practice, 114 e.v. Vir bepaalde beskouinge van en verskillende optredes deur ML King, Jr, kyk die goed gedokumenteerde biografie oor hom van W M Roger Witherspoon, Martin Luther King Jr. ... To the Mountaintop. New York 1985. W Kreck het gesê: "Die Situation in der Welt ist Heute ... objektiv revolutionär" (Grundlagen christlicher Ethik, 341). Aartsbiskop D Tutu en sy geesgenote sê: "As members of the Christian community we have no choice but to participate in the process of liberation. We have no choice but to challenge 
the forces of oppression and dehumanisation" (B Goba, in: Hammering Swords into Ploughshares, (B Tlhagale ed), Johannesburg 1986, 68). Albert Nolen sê: "it is also a time for us to act in the name of God, as the prophets did, to minimize the bloodshed..." (a.w., 139). Vgl ook J W de Gruchy, a.w., 202 e.v.

8. Die groot klem wat op die aspek van die gewete gelê word, word teruggevoer na 'n publikasie van HD Thoreau in 1849. The Duty of Civil Disobedience (vgl WR Miller, Nonviolence, $A$ Christian Interpretation. New York 1972, 71).

9. W Kreck haal 'n uitspraak van H Camara aan: "Wir Christen stehen auf Seiten der Gewaltlosigkeit... Gewaltlosigkeit bedeutet, an die Kraft der Wahrheit, der Gerechtigkeit und der Liebe mehr zu glauben als an die Kraft der Lüge, der Ungerechtigkeit und des Hasses" (Grundfragen Christlicher Ethik, 342).

10. In die Suid-Afrikaanse geskiedenis was, behalwe vir enkele individue en sporadiese groepe, die Ossewa-Brandwag, die 'Torch Commando' en die huidlge Afrikaner-Weerstandsbeweging en die African National Congres bekend vir hulle verset teen en ongeduld met die demokraties-pariementêre prosesse.

11. Op die prinsipiële verskil tussen sekularisasie en sekularisme gaan ek nie hier in nie. Daaraan het ek aandag gegee in Sterwende Christendom? ' $n$ Teologie in die greep van die ydgees. Kaapstad 1969, 19 e.v. Vgl ook G Holdijk, Christenen en Burgerlijke Ongehoorzaamheid, 55.

12. $\mathrm{Vgl}$ Leon Louw en Frances Kendall, Suid-Afrika. Die Oplossing. Johannesburg 1986, 124 $\boldsymbol{\theta} . \mathrm{v}$.

13. Gandhi self het by geleentheid gewaarsku teen die gevare van burgerlike ongehoorsaamheid. "Civil disobedience" - is a very potent weapon. But everyone cannot wield it. For that one needs training and inner strength. It requires occasions for its use" (aangehaal deur WR Miller, Nonviolence, 79). Kyk vir opmerkings oor Gandhi ook Karl Jaspers, Die Atombombe und the Zukunft des Menschen, München 1960, 65 e.v.

14. Vgl H Schlier, s.V., eleutheros in: G Kittel, Theol. Wōrterbuch /IN.T.,2 Bd., Stuttgart 1935, 497.

15. Vir Louis Waldmann bv, is sowel die beginsel as die praktyk van burgerlike ongehoorsaamheid nie aanvaarbaar nie. "Such doctrine is not only illegal and for that reason alone should be abandoned, but that it is also immoral, destructive of the principles of democratic government, and a danger to .... civil rights" (in: HA Bedau, Civil Disobedience, 107). Hy wys daarop dat bepaalde tegnieke wat deur ondersteuners van burgerlike ongehoorsaamheidsaksies gevolg word in die geskiedenis deur Kommuniste en deur Hitter gebruik is (idem, 114).

16. "Human history gives many examples of times when people of integrity had to put conscience of faithfulness to God ahead of obedience to human lawn (Richard K Taylor, in: Jim Wallis (ed), The rise of Christian conscience, San Francisco 1987, 248).

17. "Christenen zullen veel te verduren, te verdragen en te lijden hebben - zeker geestelijk, maar ook in hun handelen - alvorens ze aan de afweging toe kunnen komen of de gehoorzaamheid - partieel - moet worden opgezegd" (G Holdijk, a.w., 75). 
18. "Dit is onnodig om daarop te wys dat hierdie miskenning van hervorminge enersyds, en die felle reaksie op dié miskenning andersyds, 'n hoogs plofbare toestand skep wanneer dit daartoe lei dat die heersersgroep verdere hervorminge vertraag en selfs stopsit" (DA du Toit, in: Staatsgesag en Burgerlike Ongehoorsaamheid, 78). 